Prosiding Seminar Nasional Perubahan Iklim 2012, Sekolah Pascaasarjana, Universitas Gadjah Mada, 30 Juni 2012 


\title{
PERAN ORGANISASI MASYARAKAT DALAM STRATEGI ADAPTASI KEKERINGAN DI DUSUN TURUNAN KECAMATAN PANGGANG KABUPATEN GUNUNGKIDUL (Sebuah Pembelajaran dalam Adaptasi Dampak Perubahan Iklim di Masa Mendatang)
}

\author{
Ahmad Cahyadi $^{1}$, Henky Nugraha ${ }^{2}$, Dhandhun Wacano ${ }^{3}$, Hendy Fatchurohman ${ }^{4}$ \\ 1,2,3 Magister Perencanaan Pengelolaan Pesisir dan Daerah Aliran Sungai (MPPDAS) \\ Fakultas Geografi Universitas Gadjah Mada Yogyakarta \\ ${ }^{4}$ Jurusan Geografi Lingkungan Fakultas Geografi Universitas Gadjah Mada Yogyakarta \\ ${ }^{1,2,3,4}$ Karst Student Forum (KSF) Fakultas Geografi Universitas Gadjah Mada \\ Email: ahya.edelweiss@gmail.com
}

\section{INTISARI}

Kondisi fisik kawasan karst yang didominhasi oleh bentuklahan hasil proses pelarutan batuan menyebabkan berkembanganya sistem pelorongan, drainase bawah tanah dan sistem gua. Hal tersebut menyebabkan kelangkaan air di bagian permukaan sehingga kawasan karst lebih dikenal sebagai kawasan yang rawan terhadap bencana kekeringan. Penelitian ini bertujuan untuk (1) mengetahui peranan organisasi masyarakat lokal dalam pengelolaan sumberdaya air yang terbatas pada musim kemarau di Dusun Turunan, Kecamatan Panggang, kabupaten Gunungkidul, dan (2) mengidentifikasi strategi adaptasi masyarakat dalam menghadapi bencana kekeringan di kawasan karst. Hasil penelitian menunjukkan bahwa organisasi masyarakat berperan sangat besar dalam pengelolaan sumberdaya air pada musim kemarau. Organisasi ini berperan dalam pembagian jatah air, pengoperasian pompa, perawatan dan pengelolaan instalasi penyedia air, dan pengawasan terhadap pemanfaatan air. Strategi adaptasi terhadap bencana kekeringan yang dilakukan berupa larangan memandikan ternak, larangan mencuci motor, serta pembagian penyaluran air untuk masing-masing kelompok rukun tetangga.

Kata Kunci: Organisasi Masyarakat, Strategi Adaptasi, Kekeringan, Karst

\section{PENDAHULUAN}

Proses pelarutan batuan yang terjadi akibat adanya interaksi air hujan, karbondioksida dan batuan karbonat telah menyebabkan terbentuknya kawasan karst (Ford dan William, 1992). Proses tersebut menyebabkan terbentuknya sistem pelorongan, drainase bawah tanah, sistem gua serta celahcelah pelarutan yang menyebabkan air di permukaan dalam waktu singkat masuk ke dalam sistem bawah tanah (White, 1988). Hal ini menyebabkan kondisi kering di permukaan, sehingga sumber air di permukaan jarang sekali ditemukan (Cahyadi, 2010). Hal inilah yang menyebabkan kawasan karst terkenal sebagai kawasan yang rawan terhadap bencana kekeringan (Suryanti dkk. 2010).

Jarangnya sumber air permukaan di kawasan karst menyebabkan mataair dan telaga yang merupakan sumber air dipermukaan menjadi sangat penting (Worosuprojo dkk, 1997; Santosa, 2007). Jumlah air yang terbatas dibandingkan jumlah kebutuhan yang banyak tentunya akan mendorong terbentuknya pola adaptasi masyarakat (Awang, 2005). Hal ini karena secara naluriah manusia akan berusaha bertahan hidup dalam kondisi keterbatasan (Twigg, 2004). Namun demikian, dalam bertahan hidup tersebut, manusia dikontrol oleh norma-norma yang berlaku sehingga kemudian memunculkan pola adaptasi yang unik dan khas di dalam kelompok masyarakat (Sudarmaji dkk, 2012). 
Penelitian ini dilakukan di Dusun Turunan, Desa Girisuko, Kecamatan Panggang, Kabupaten Gunungkidul. Dusun ini menggunakan satu mataair untuk memenuhi kebutuhan masyarakat. Tujuan penelitian ini adalah untuk (1) mengetahui peranan organisasi masyarakat lokal dalam pengelolaan sumberdaya air yang terbatas pada musim kemarau di Dusun Turunan, Desa Girisuko, Kecamatan Panggang, Kabupaten Gunungkidul, dan (2) mengidentifikasi strategi adaptasi masyarakat dalam menghadapi bencana kekeringan di kawasan karst. Berdasarkan hasil penelitian ini, maka diharapkan dapat diperoleh pembelajaran dalam menghadapi kekeringan. Hal ini dapat dilakukan karena pola adaptasi yang ada di suatu tempat dapat dijadikan suatu model untuk diterapkan ditempat lain dengan persoalan yang sama, tetapi tentunya harus dengan modifikasi-modifikasi dan penyesuaian dengan kondisi wilayah yang lain. Pola adaptasi ini menjadi penting dalam upaya pengurangan risiko bencana kekeringan, yang menurut banyak penelitian akan lebih sering terjadi akibat dampak dari perubahan iklim.

\section{METODE PENELITIAN}

Metode yang digunakan dalam penelitian ini adalah wawancara mendalam (in-depth interview). Penentuan responden dilakukan berdasarkan survei pendahuluan di lokasi penelitian. Berdasarkan hasil survei pendahuluan kemudian ditentukan responden yang terdiri dari tokoh masyarakat, pengelola, teknisi jaringan penyediaan air, serta masyarakat yang menjadi pemakai dari sumber air.

\section{HASIL DAN PEMBAHASAN}

Mataair Nganjan menjadi sumber utama penyediaan air minum di Dusun Turunan, Desa Girisuko, Kecamatan Panggang, Kabupaten Gunungkidul (Gambar 1). Sebelum dibentuk organisasi masyarakat pengelola air, warga mengambil air dari mataair ini dengan jerigen, galon ataupun klenting (wadah air dari tanah) dan dibawa ke rumah dengan digendong atau dipanggul. Kondisi topografi yang berbukit tentunya menyebabkan pekerjaan mengambil air menjadi pekerjaan yang membutuhkan tenaga dan waktu yang banyak. Selain itu, sebelum ada organisasi pengelola air, pengambilan air seringkali dilakukan secara bersama-sama sehingga menyebabkan antrian dan seringkali menjadikan masyarakat tidak dapat melakukan pekerjaan yang lain. 


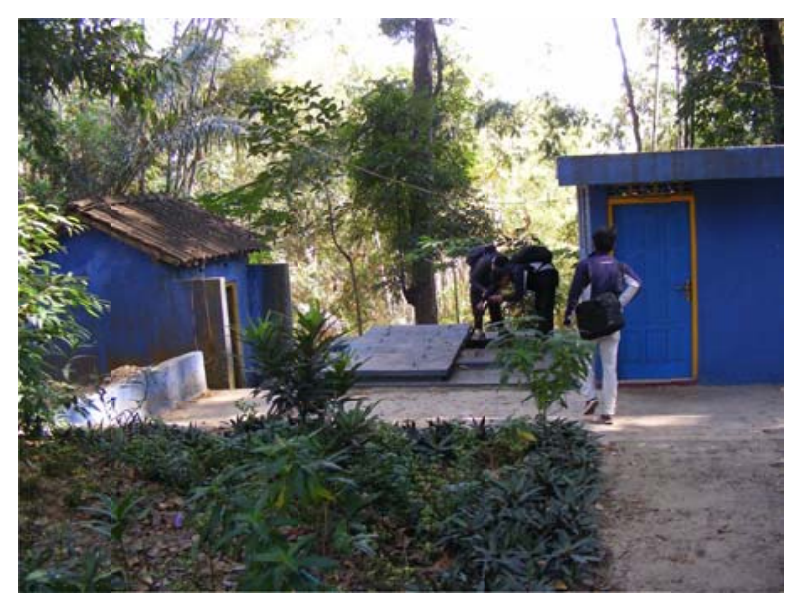

Gambar 1. Instalasi Air Bersih di Mataair Nganjan Dusun Turunan

Pembentukan organisasi masyarakat yang mengelola Mataair Nganjan dipelopori oleh sebuah lembaga sosial masyarakat (LSM) dari luar Dusun Turunan. Lembaga ini memberikan bantuan dalam wujud pembangunan instalasi penyaluran air, pompa, dan memfasilitasi pembuatan organisasi masyarakat pengelola air dan mendampingi dalam proses pembuatan samapi dengan pembuatan aturan-aturan dalam pengelolaan air. Pengelolaan mataair kemudian dilakukan dengan membuat beberapa bak penampungan air, di mana salah satu bak penampungan digunakan untuk sumber air yang dipompa ke penampungan induk yang terletak di atas bukit. Air dari tampungan induk kemudian dialirkan ke rumah-rumah warga. Dengan demikian, maka warga tidak perlu antri dan menghabiskan waktu untuk mengambil air. Selain itu, tenaga yang dibutuhkan sedikit dan masayrakat memiliki waktu yang lebih untuk melakukan pekerjaan yang lain.

Organisasi pengelola air di Dusun Turunan bertugas untuk menjamin terjaganya aliran air yang dipompa, merawat jaringan pipa dan pompa, melayani pemasangan pipa, mengumpulkan iuran bulanan dari masayrakat dan mengelolanya sebagai biaya perawatan serta mengatur pergiliran aliran air dan pembatasan pemanfaatan air pada waktu musim kemarau. Oraganisasi ini menunjuk beberapa pegawai yang setiap hari mengecek instalasi air sekaligus bertugas memperbaiki apabila terjadi kerusakan. Biaya operasional diperoleh dari iuran warga sebesae Rp 2.000,00 per bulan.

Strategi adaptasi terhadap kekeringan yang diterapkan masyarakat terkait dengan pemenuhan kebutuhan air diatur pula oleh kelompok pengelola air. Beberapa larangan yang diberlakukan pada saat musim kemarau diantaranya adalah larangan mencuci ternak, larangan mencuci kendaraan, larangan mengambil air langsung dari mataair, pembatasan penggunaan oleh rumah tangga, serta pergiliran penggunaan per rukun tetangga (RT). Hal ini dilakukan untuk menjamin air dapat terbagi secara merata bagi masyarakat di dusun turunan.

\section{PENUTUP}

Berdasarkan hasil penelitian yang telah dilakukan, maka diperolehe beberapa kesimpula sebagai berikut: 
1. Organisasi masyarakat lokal berperan sangat besar dalam pengelolaan sumberdaya air pada musim kemarau. Organisasi ini berperan dalam pembagian jatah air, pengoperasian pompa, perawatan dan pengelolaan instalasi penyedia air, dan pengawasan terhadap pemanfaatan air.

2. Strategi adaptasi terhadap bencana kekeringan yang dilakukan berupa larangan memandikan ternak, larangan mencuci motor, serta pembagian penyaluran air untuk masing-masing kelompok rukun tetangga. Intinya bahwa masyarakat melakukan gerakan hemat air dengan membatasi pemakaian dan peruntukan air.

\section{DAFTAR PUSTAKA}

Awang, San Afri. 2005. Kelangkaan Air: Mitos Sosial, Kiat, dan Ekonomi Rakyat. Yogyakarta: Debut Press.

Cahyadi, Ahmad. 2010. Pengelolaan Kawasan Karst dan Peranannya dalam Siklus Karbon di Indonesia. Paper on Seminar Nasional Perubahan Iklim di Indonesia. Sekolah Pasca Sarjana UGM Yogyakarta, 13 Oktober 2010.

Ford, D. and Williams, P. 1992. Karst Geomorphology and Hydrology. London: Chapman and Hall.

Santosa, Langgeng Wahyu. 2007.Kerusakan Telaga Dolin dan Faktor-Faktornya di Wilayah Perbukitan Karst Kabupaten Gunungkidul. Jurnal Kebencanaan Indonesia, Vol. 1(3): 176-193.

Sudarmaji; Suprayogi, Slamet dan Setiadi. 2012. Konservasi Mataair Berbasis Masyarakat di Kabupaten Gunungkidul. Yogyakarta: Sekolah Pascasarjana Universitas Gadjah Mada.

Suryanti, E.D.; Sudibyakto, dan Baiquni, M. 2010. Strategi Adaptasi Ekologis Masyarakat di Kawasan Karst Gunungsewu dalam Mengatas Bencana Kekeringan. Jurnal Kebencanaan Indonesia, Vol. 2(3). Hal: 658-673.

Twigg, John. 2004. Disaster Risk Reduction: Mitigation and Preparedness in Development and Emergency Programming. London: Overseas Development Institute.

White, W.B., 1988. Geomorphology and Hydrology of Karst Terrains. New York : Oxford University Press.

Worosuprojo, Suratman; Suyono; Risyanto; Adji, Tjahyo Nugroho. 1997. Kajian Ekosistem Karst di Kabupaten Gunungkidul Provinsi Daerah Istimewa Yogyakarta. Laporan Penelitian. Biro Bina Lingkungan Hidup Provinsi Daerah Istimewa Yogyakarta dan Fakultas Geografi Universitas Gadjah Mada. 
